\title{
Early Cretaceous Index Benthic Foraminifera from Northeast of Torbat-e-Heydarieh Area (Esfiyukh Section)
}

\author{
Nahid Khodashenas, Ali Asghar Aryaei, Ali Reza Ashouri \\ Department of Geology, Mashhad Branch, Islamic Azad University, Mashhad, Iran \\ Email:wpu.gama@gmail.com
}

Received 2 February 2014; revised 2 March 2014; accepted 10 March 2014

Copyright (C) 2014 by authors and Scientific Research Publishing Inc.

This work is licensed under the Creative Commons Attribution International License (CC BY).

http://creativecommons.org/licenses/by/4.0/

(c) () Open Access

\section{Abstract}

The first study of early cretaceous succession in Northeast of Torbat-e-Heydarieh, led to recognition of 30 genera and 25 species of benthic foraminifera such as Rectodictyorbitolina sp., Dictyoconus arabicus, Orbitolina discoidea, Palorbitolina lenticularis, Mesorbitolina parva, Orbitolina kurdica, Praeorbitolina sp., Valvullammina picardi, Pseudocyclamina lituus, Charentia cuvillieri, Lenticulina sp., Nezzazata picardi, Quinqueloculina robusta, Nautiloculina oolitica, Subaudia minuta, Praechrysalidina infracteracea, Rumanoloculina sp., Choffahella decipiens, Vercorsella arenata. Regard to Stratigraphy range of above mentioned, the Barremian-Aptian age suggested for this succession.

\section{Keywords}

Torbat-e-Heydarieh, Cretaceous, Benthic Foraminifera

\section{Introduction}

Stratigraphic cuts located in Razavi Khorasan, 5 km from NE Torbat Heydarieh, in the Esfiyukh section region have been studied; and the geographical characteristics of this cut with the longitude 5915 and the latitude of 35 20; 60 thin sections are studied [1].

\section{Discussion}

Sediments thickness in this cut is about $175 \mathrm{~m}$, and consists of Alternatives lime including medium thick layer to 
very thick layer. This section with a few meters of conglomerates is held on the Jurassic or older sediments and contains red dark red sand stone to brown sand stone with angular conformity; this section is also covered in the same format with the cretaceous sediments or younger ones.

Target sequence from bottom to top are:

1) Massive gray limestone containing microfossil orbitolina (5/21 m).

2) Brown) gray fossiliferous limestone containing abundant rudist (5/1 meter).

3) Massive gray limestone containing microfossil orbitolina (71 meters).

4) Dolomite (5/0 mm).

5) Thick limestone layer containing a light gray and brown algae and calcareous microfossil orbitolina (80 meters).

Microscopic study of thin sections led to the identification of 30 genera and 25 species of fossil benthic foraminifera as below:

Choffatella decipiens, Vercorsella arenata, Cuneolina camposaurii, Pseudocyclamina hedbergi, Cuneolina pavonia, Maynsina sp., Debarina hahounerensis, Pseudocyclamina lituus, Charentia cuvillieri, Lenticulina sp., Nezzazata picardi, Quinqueloculina robusta, Nautiloculina oolitica, Subaudia minuta, Praechrysalidina infracteracea, Rumanoloculina sp. Valvullammina picardi, Orbitolina conoidea, Rectodictyorbitolina sp., Dictyoconus arabicus, Orbitolina discoidea, Palorbitolina lenticularis, Mesorbitolina lotzei, Orbitolina kurdica, Praeorbitolina sp., Chrysalidina gradata, Everticyclammina hedbergi, Mesorbitolina parva, Praeorbitolina cormeyi, Dictyoconus pachymarginalis [2]-[6].

The age of foraminifera Barremian-Aptian is proposed for the sequence which is shown in the Figure 1 and Figure 2. Some of benthic foraminifera section Esfiyukh Mountain are listed and shown in the Figure 3. The names of these sections are also referred in the below based on A, B, .. X.

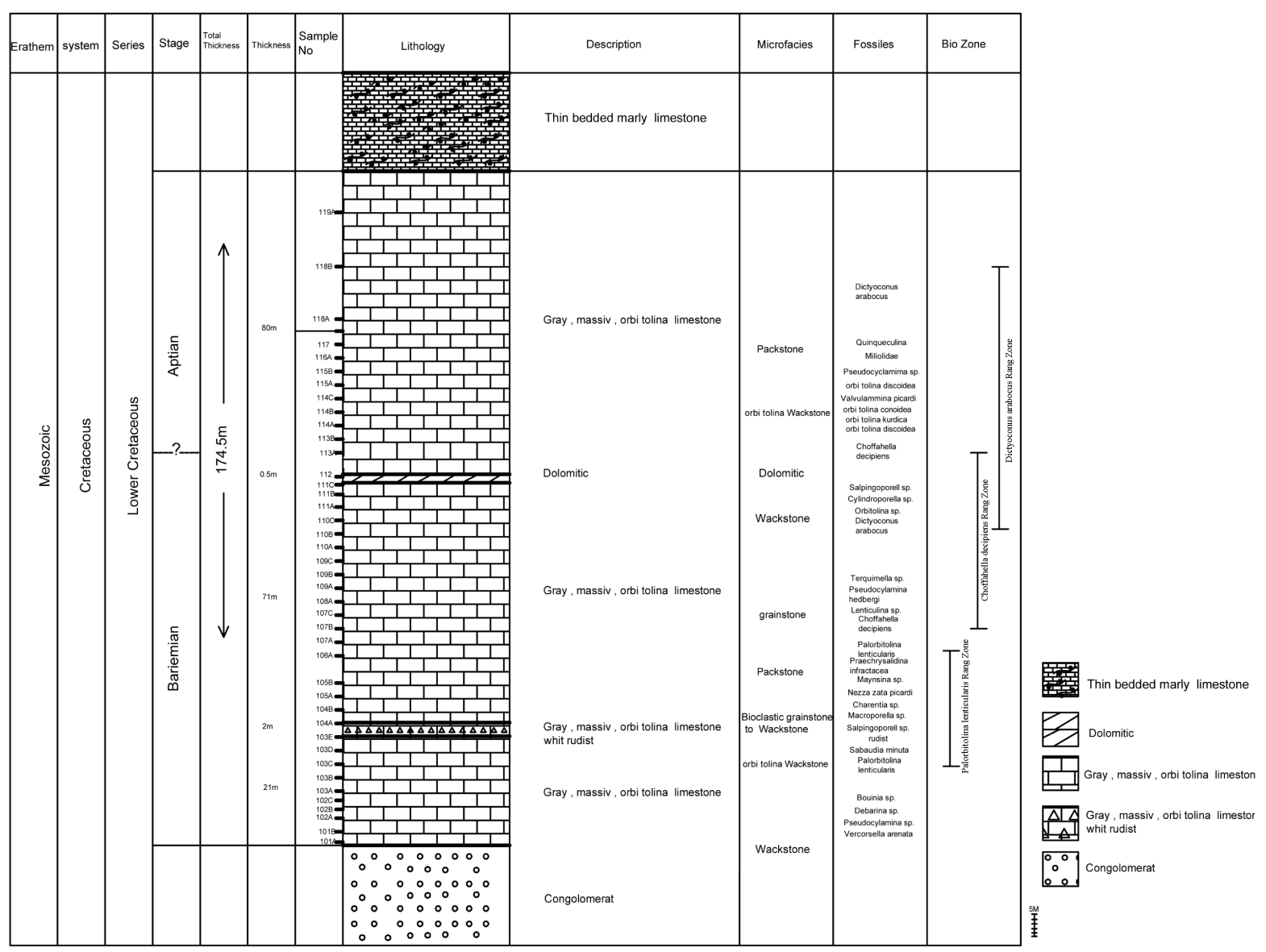

Figure 1. Stratigraphic column of time developing benthic foraminifera in Esfiyukh section. 


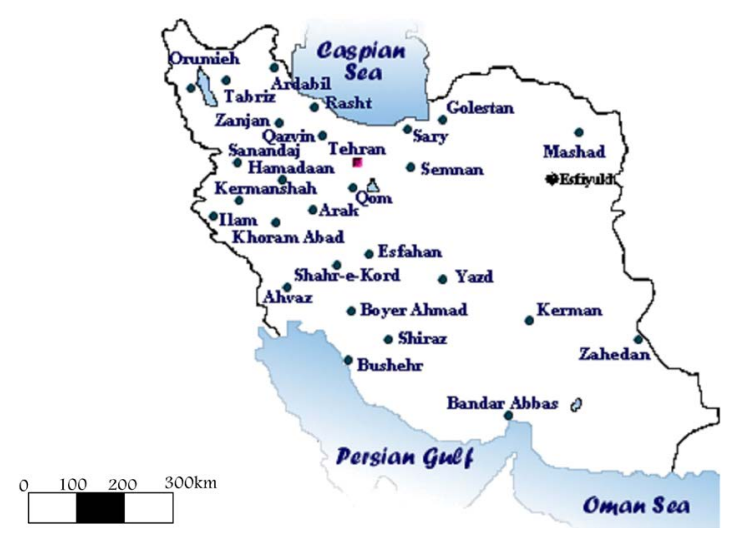

Figure 2. Geographical map of Esfiyukh.

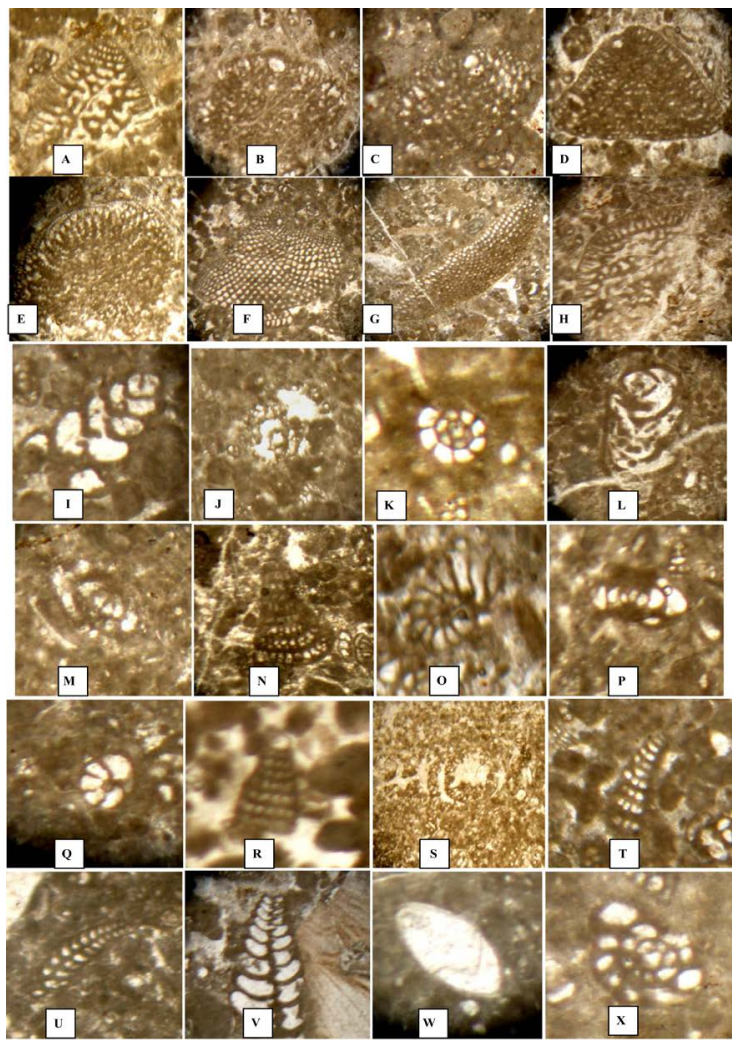

Figure 3. Some of benthic foraminifera Esfiyukh section

[2]-[6]. Plate 1 A. Praeorbitolina sp. cf. P. cormeyi $(\times 100)$; B. Mesorbitolina lotzei $(\times 100)$; C. Palorbitolina lenticularis $(\times 100)$; D. Dictyoconus pachymarginalis $(\times 100)$; E. Dictyoconus arabicu $(\times 100) ;$ F. Mesorbitolina parva $(\times 100)$; G. Dictyoconus ichnusae $(\times 100)$; H. Rectodictyorbitolina sp. $(\times 100)$; I. Everticyclammina hedbergi (×120); J. Debarina sp. $(\times 120)$; L. Chrysalidina gradate; M. Cuneolina camposaurii $(\times 120)$; N. Choffahella decipiens $(\times 120)$; O. Nautiloculina oolitica; P. Charentia cuvillieri $(\times 120)$; Q. Cuneolina pavonia $(\times 120)$; R. Pseudocyclamina lituus $(\times 120)$; S. Subaudia minuta $(\times 120)$; T. Valvullammina picardi $(\times 120)$; U. Maynsina sp. $(\times 120)$; V. Lenticulina sp. $(\times 120)$; W. Praechrysalidina infracterace $(\times 120)$; X. Vercorsella arenata $(\times 120)$. 


\section{Conclusion}

In this research, for the first time biostratigraphic characteristics of Esfiyukh Mountain located $5 \mathrm{~km}$ north of East Torbat Heydarieh have been studied. The sediment thickness is $175 \mathrm{~m}$ and involves sections Medium to very thick layer alternatively limestone. This section with a few meters of conglomerates is held on the Jurassic or older sediments and contains red dark to brown sand stone with angular conformity; this section is also covered in the same format with the cretaceous sediments or younger ones. Study of microfossils in this section led to 30 genera and 25 species of fossil of benthic foraminifera as mentioned in passage. The age of the sequence is proposed Barremian-Aptian.

\section{References}

[1] Ave, K. (2007) Micro Facies. Tehran University, Tehran, 498.

[2] Loblich, A.R. and Tappan, H. (1988) Foraminifera Genera and Their Classification. Van NOSTRD Reinhold Company, New York, 970. http://dx.doi.org/10.1007/978-1-4899-5760-3

[3] Schroeder, R. and Schenk, K. (1968) Sur Lapresence de grands foraminiferes d age Aptien superieur dans Iurgonien de la Napped u Wildhorn (Suisse centrale) Note preliminaire. Revue de paleobiologie, Geneve, 26, 665-669.

[4] Arnaud-Vanneau, A. (1998) Larger Benthic Foraminifera. In: Hardenbol, J., Jacquin, T., Farley, M.B., de Graciansky, P.C. and Vail, P., Eds., Cretaceous Biochronostratigraphy, SEPM Special Publication, Tulsa, 60.

[5] Wilson, J.L. (1975) Carbonate Facies in Geologic History. Springer Verlag, Berlin, 471. http://dx.doi.org/10.1007/978-1-4612-6383-8

[6] Husinec, A. and Sokac, B. (2006) Early Cretaceous Benthic Association of a Shallow Tropical-Water Platform Environment (Mljet Island, Southern Croatia). Cretaceous Research, 27, 418-441. http://dx.doi.org/10.1016/j.cretres.2005.07.008 
Scientific Research Publishing (SCIRP) is one of the largest Open Access journal publishers. It is currently publishing more than 200 open access, online, peer-reviewed journals covering a wide range of academic disciplines. SCIRP serves the worldwide academic communities and contributes to the progress and application of science with its publication.

Other selected journals from SCIRP are listed as below. Submit your manuscript to us via either submit@scirp.org or Online Submission Portal.
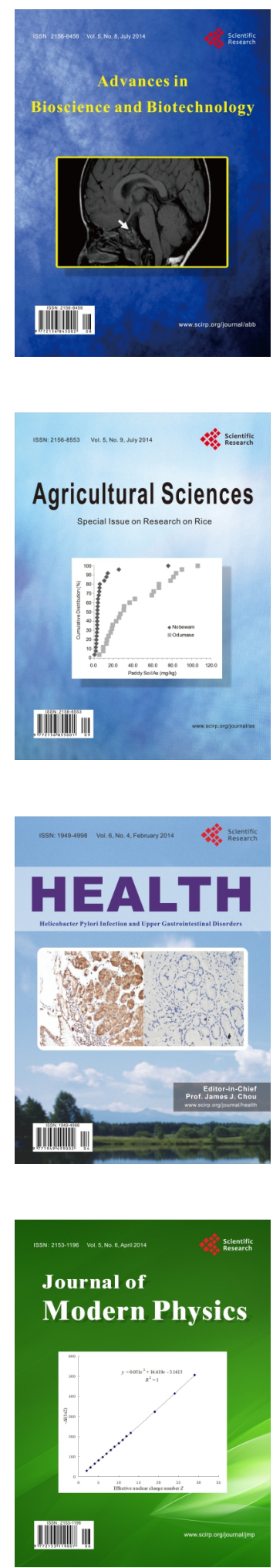
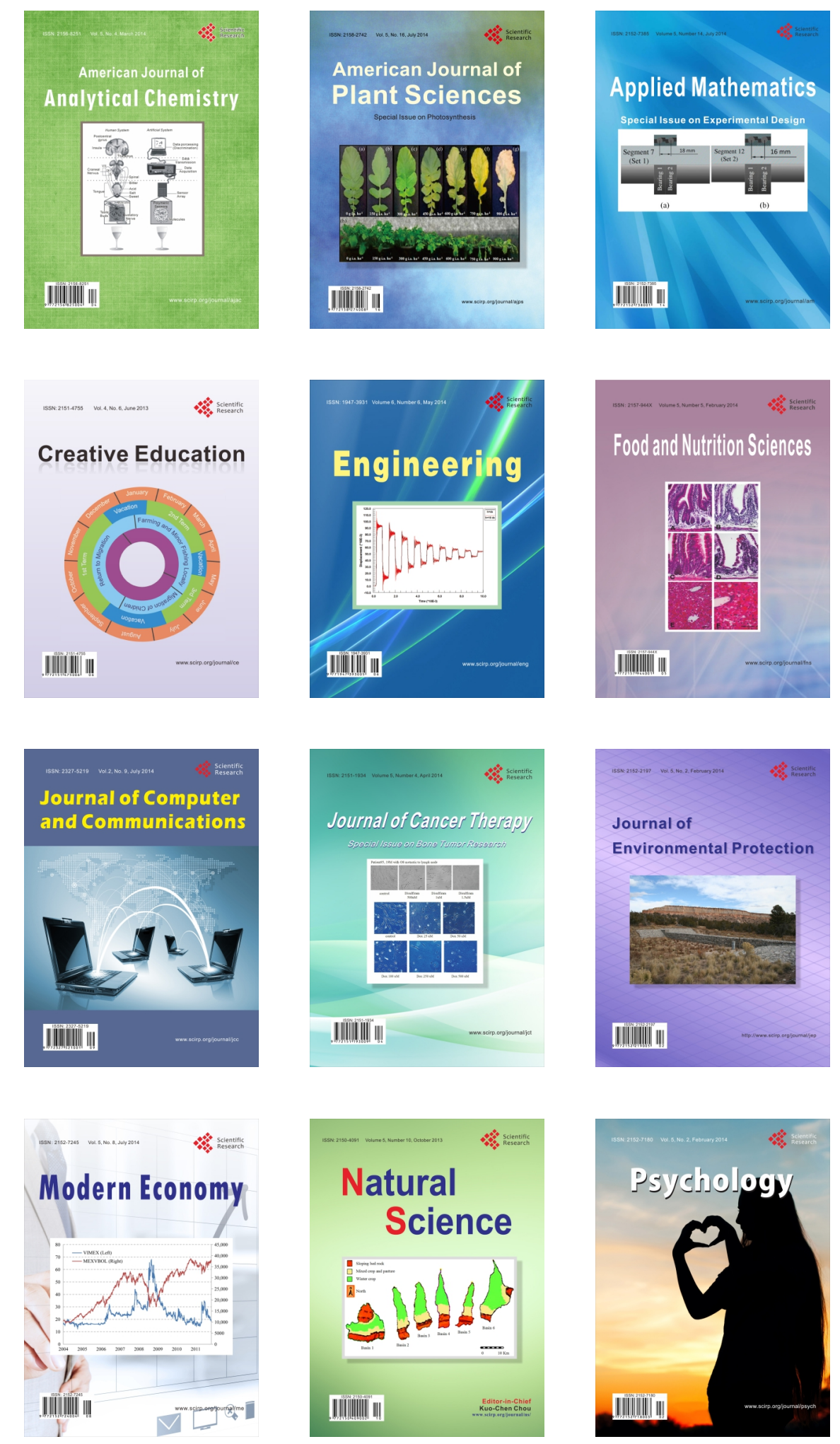